\title{
Efficient cryopreservation by droplet vitrification of pentaploid roses and the phenotype of regenerated plants
}

\author{
Bożena Pawłowska*, Bożena Szewczyk-Taranek \\ Department of Ornamental Plants, University of Agriculture in Kraków, Al. 29 Listopada 54, 31-425 Kraków, Poland
}

\begin{abstract}
Shoot tips from in vitro plants of four rose species were cryopreserved by the droplet vitrification method. Optimized conditions involved exposure to loading solution for $20 \mathrm{~min}$, then treatment with plant vitrification solution (PVS2) for 20 $\min$ (Rosa agrestis, $R$. canina and $R$. dumalis) or $30 \mathrm{~min}$ (R. rubiginosa) followed by freezing in liquid nitrogen. Survival rate ranged from 78.3 to $95.1 \%$, depending on the species. Regrowth rate of shoot tips was $50.5 \%$ for $R$. agrestis, $63.2 \%$ for $R$. rubiginosa, $71.4 \%$ for $R$. dumalis and $78 \%$ for $R$. canina. The preculture of donor plants in a medium with $0.25 \mu \mathrm{M}$ sucrose facilitated the isolation of shoot tips and increased regrowth rate after cryopreservation. Plant regeneration was carried out in Murashige and Skoog medium with $1 \mu \mathrm{M}$ 6-benzylaminopurine, $1.5 \mu \mathrm{M}$ gibberellic acid and $0.087 \mathrm{M}$ sucrose. Plants regenerated from cryopreserved shoot tips did not display morphological alterations in comparison with non-cryopreserved shoot tip - derived plants.
\end{abstract}

Keywords: Caninae; dog roses; shoot tips; preculture; in vitro; liquid nitrogen

\section{Introduction}

Rosa is one of the major economically important genera in floriculture. Pentaploid roses from Caninae section $(2 n$ $=5 x=35$ ) are a source of plant material for breeding. The specific type of meiosis in Caninae contributes to the great morphological diversity of dog roses [1].

Cryopreservation is a technique used to ensure safe and cost-efficient, long-term conservation of germplasm. Most explants require a special protection for liquid nitrogen (LN) conservation, which must be developed for each method of cryopreservation [2]. In vitro precultures of donor plants or explants were applied to induce the tolerance to low temperature by using of media containing either a higher than standard concentration of carbohydrates (sucrose, glucose) and $\mathrm{ABA}$, proline or activated charcoal $[3,4]$.

A few reports on the rose cryopreservation of shoot tips collected from in vitro grown plants have described encapsulation-dehydration $[4,5]$ and droplet vitrification [6-8]. Recently, the plant material from greenhouse-grown R. chinensis 'Old Blush' [9] and from in situ [10] have been cryopreserved.

Morphological, physiological, biochemical and genetic stability of regenerants need to remain unaltered by the process of cryopreservation. Prior to the implementation of

\footnotetext{
* Corresponding author. Email: ropawlow@cyf-kr.edu.p
}

Handling Editor: Krystyna Klimaszewska cryopreservation protocols, in the global germplasm storage projects, regenerants should be monitored as reported in banana meristem cryopreservation [11].

The aim of this study was to optimize the droplet vitrification protocol to improve the efficiency of the shoot tip cryopreservation of in vitro-grown four species of pentaploid roses and to evaluate the effect of donor plant preculture. To assess the influence of cryostorage, the morphology of the regenerated plants was compared with the donors.

\section{Material and methods}

The shoots of fieldbriar rose Rosa agrestis Savi, dog rose $R$. canina L., glaucous dog rose $R$. dumalis Bechst. and sweetbriar rose $R$. rubiginosa $\mathrm{L}$. were micropropagated on the Murashige and Skoog (MS) [12] medium with $1 \mu \mathrm{M}$ 6-benzylaminopurine (BA), $1.5 \mu \mathrm{M}$ gibberellic acid $\left(\mathrm{GA}_{3}\right)$, $0.087 \mathrm{M}$ sucrose and $0.7 \%$ agar Difco $^{\circ}$ Bacto $^{\circ}$, pH 5.7 (rose multiplication medium; RMM). Cultures were maintained in a 16-hour photoperiod at photosynthetic photon flux density (PPFD) $30 \mu \mathrm{mol} \mathrm{m}{ }^{-2} \mathrm{~s}^{-1}$ (Philips TL-D 36W/54), at 23/25 $\pm 1^{\circ} \mathrm{C}$ (night/day). Donor plants were cultivated for seven weeks on a preculture medium supplemented with abscisic acid (ABA; $3.8 \mu \mathrm{M})$, proline $(2.15 \mathrm{mM})$ or sucrose $(0.25 \mathrm{M})$. The excised shoot tip consisted of a meristem covered with one or two leaf primordia and a piece of stem.

The dry mass content (DM) of explants was determined prior to the application of cryoprotectants. The samples (30 
explants per dish) were dried at $65^{\circ} \mathrm{C}$ in a Sanyo MOV-112S oven, until constant weight.

For cryopreservation, a method described by Pawłowska nad Szewczyk-Taranek [10] was applied with the modification of PVS2 (plant vitrification solution) treatment time $(10,20$, or $30 \mathrm{~min})$. In the experiments testing preculture media the PVS2 treatment was for $20 \mathrm{~min}$.

The developing axillary shoots were subcultured every 5 weeks on RMM. After 7 months shoots rooted on plant regulator-free (PGR) medium. Plantlets were acclimatized in a greenhouse and were evaluated after 4 weeks.

To assess the cryopreservation efficiency, the number of alive explants was observed at 25th day after droplet rewarming (the survival rate). Regrowth rate corresponding to the development of shoots from all cryopreserved explants was calculated 55 days after rewarming. Biometrical observations involved: shoot multiplication rate and height of the plants, number of rooted shoots and number of roots per shoot.

Each variable of the cryopreservation experiments was tested in triplicate, with 15-20 explants per replicate. Plant regeneration (shoot micropropagation, rooting, acclimatization) was carried out in 5 replicates with 25 explants per each replicate.

Data were subjected to ANOVA using Statistica 9 software (StatSoft), and the means were compared by Duncan's test, $\alpha \leq 0.05$.

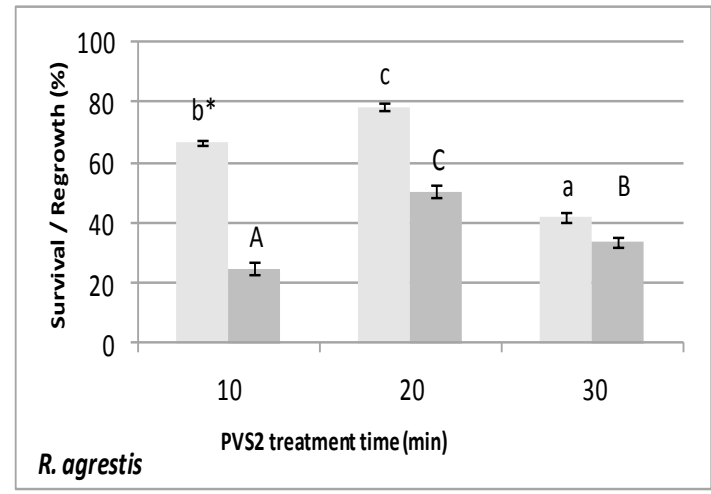

a

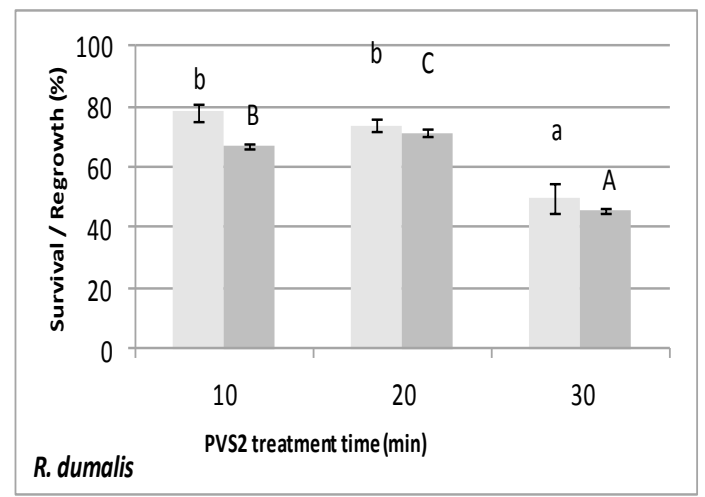

c

Fig. 1 Effect of 20 min LS and varius PVS2 treatment time on survival and regrowth rate of Rosa agrestis (a), R. canina (b), $R$. dumalis (c) and R. rubiginosa (d) shoot tips after cryopreservation. ${ }^{*}$ Means for the examined attributes with the same letter are not significantly different at $\alpha=0.05$, statistical analyses were performed separately for each rose species.

\section{Results and discussion}

We established the efficient cryopresevation protocol for four species of Caninae rose shoot tips, and assessed the morphology of regenerated plants recovered from LN storage.

Exposure to PVS2 was critical and affected the survival and regrowth rate after the cryopreservation. The highest survival rates of $R$. agrestis and $R$. canina explants were observed after $20 \mathrm{~min}$ of exposure to PVS2, 78.6\% and 95.1\%, respectively (Fig. 1a,b). The survival rate of $R$. dumalis was high after 20 or 10 min PVS2 ranging from 73.9 to 78.3\% (Fig. 1c), whereas the optimal PVS2 treatment for R. rubiginosa explants was $30 \mathrm{~min}$ (87.5\%; Fig. 1d). Similar trend was observed after 55 days post re-warming of the droplets, however the regrowth rate was lower in comparison with the survival rate. The highest regrowth rate was recorded for the shoot tips of $R$. canina (78.6\%), followed by $R$. dumalis (71.4\%), R. rubiginosa (63.2\%) and R. agrestis (50.5\%; Fig. 1a-d).

Apical meristems guarantee the highest genetic stability of post-cryopreserved regenerated plants and are more suitable as explants for storage in gene banks than the callus or cell suspension cultures. Undifferentiated meristematic cells with a low water content usually demonstrate high post-thawing survival and regrowth rates [2,13].

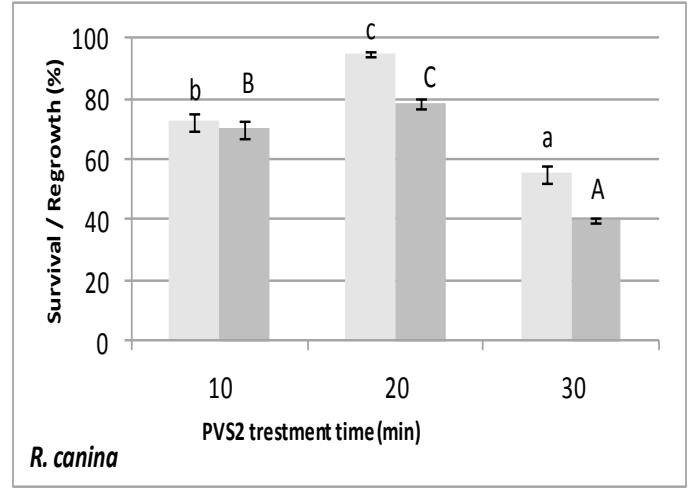

b

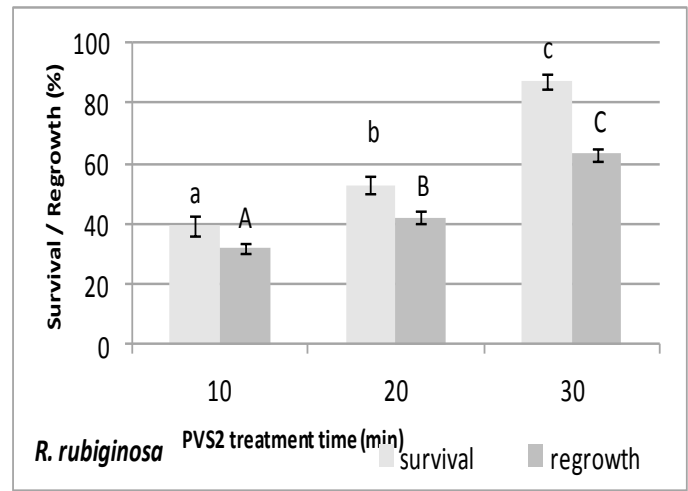

d 
All the preculture media increased the dry mass content in the explants. Donor plants cultivated on $0.25 \mathrm{M}$ sucrose had the highest DM (31.8-32.9\%; Tab. 1). The DM of plants precultured on ABA was 30-31.5\%, while for those precultured on proline was lower (23.2-24.1\%). For reference, the DM of control explants was 22.1-22.5\% (Tab. 1). Preculture media affected the survival and regrowth rate. In R. canina, preculture did not improve survival, whereas ABA preculture decreased the survival of $R$. agrestis: control survived at $78.6 \%$ vs. ABA $58.5 \%$ (Tab. 1). Explant preculture on a medium with $0.25 \mathrm{M}$ sucrose resulted in higher survival rate of $R$. dumalis, and better regrowth rates of remaining species (R. agrestis, $R$. canina, $R$. rubiginosa; Tab. 1). Plants from sucrose preculture were solid and thick, consequently the shoot tips were larger and easier to excise. In contrast, plants from proline preculture were thin and without turgor, which made preparation of explants for cryopreservation difficult and cannot be recommended.

Sugars play an important role in the acquisition of tolerance to desiccation and to LN exposure. Halmagyi and Pinker [7] successfully used pretreatment of rose apical buds on a medium with higher than standard sucrose content $(0.5$ $\mathrm{M})$. The explants from in vitro cultures had relatively low dry mass content, as compared with tissues naturally protected against low temperatures, e.g., rose shoot tips from in situ plants, collected from dormant buds in January, which had the water content of $44-52 \%$ DM [10]. Notwithstanding, we decided to preculture the donor plants and test the media with $\mathrm{ABA}$ and proline according to Burritt [3] to reduce the water content of the shoot tips to $20-30 \%$ [2].

Phenotype biometric examination during the in vitro growth stage did not reveal any morphological abnormalities compared with the non-cryopreserved plants. Although rose species showed different multiplication rates, no statistically significant differences were observed between plants regenerated in vitro (control) and those regenerated in vitro after cryopreservation. Similarly, the height of plants (approximately $25 \mathrm{~mm}$ ) did not differ between the control and post-cryopreserved plants (Tab. 2). Detailed observations during the rooting stage revealed that $59-89.3 \%$ of the plants formed adventitious roots. Control shoots of $R$. dumalis and $R$. rubiginosa, rooted better in comparison with the post-cryopreserved shoots, while there were no differences in rooting between the control and cryopreserved shoots of $R$. agrestis and R. canina. The number of roots per plant was 1.8-3.4. After 4 weeks of acclimatization, $93-100 \%$ of rooted shoots developed new leaves (Tab. 2).

When applying cryopreservation, it is important to confirm that the tissue is capable of regeneration of true-totype plants. The evaluation of phenotypic markers remains a relevant strategy to assess the stability of the cryopreserved material. The visual observations are the easiest and the most inexpensive methods that are used in the first stage of testing the post-cryopreservation plants for genetic fidelity required for validation of the cryopreservation protocol $[11,13]$.

Tab. 1 Dry mass content, the survival and regrowth of rose shoot tips after 7-week preculture on ABA, proline and sucrose medium.

\begin{tabular}{|c|c|c|c|c|}
\hline & Preculture medium & Dry mass (\%) & Survival (\%) & Regrowth (\%) \\
\hline \multirow[t]{4}{*}{ R. agrestis } & control & $22.2 \mathrm{a} \pm 0.8$ & $78.6 c^{*} \pm 2.4$ & $50.5 \mathrm{a} \pm 3.5$ \\
\hline & $3.8 \mu \mathrm{M}$ ABA & $30.9 \mathrm{~cd} \pm 0.5$ & $58.5 \mathrm{a} \pm 1.5$ & $52.2 \mathrm{a} \pm 2.2$ \\
\hline & $2.15 \mathrm{mM}$ proline & $23.2 \mathrm{ab} \pm 0.4$ & $79.6 \mathrm{c} \pm 2.6$ & $78.3 c \pm 2.7$ \\
\hline & $0.25 \mathrm{M}$ sucrose & $32.7 \mathrm{e} \pm 1.3$ & $71.5 \mathrm{~b} \pm 1.9$ & $69.5 \mathrm{~b} \pm 3.2$ \\
\hline \multirow[t]{4}{*}{ R. canina } & control & $22.1 \mathrm{a} \pm 0.8$ & $95.1 \mathrm{a} \pm 4.9$ & $78.6 \mathrm{a} \pm 3.4$ \\
\hline & $3.8 \mu \mathrm{M} \mathrm{ABA}$ & $30.0 \mathrm{c} \pm 1.1$ & $93.2 \mathrm{a} \pm 1.8$ & $80.0 \mathrm{a} \pm 2.0$ \\
\hline & $2.15 \mathrm{mM}$ proline & $23.7 \mathrm{ab} \pm 0.8$ & $91.5 \mathrm{a} \pm 3.5$ & $81.3 \mathrm{a} \pm 2.3$ \\
\hline & $0.25 \mathrm{M}$ sucrose & 32.9 e \pm 0.5 & $95.3 \mathrm{a} \pm 1.5$ & $87.6 \mathrm{~b} \pm 2.1$ \\
\hline \multirow[t]{4}{*}{ R. dumalis } & control & 22.1 a \pm 0.2 & $73.9 \mathrm{a} \pm 3.0$ & $71.4 \mathrm{~b} \pm 2.6$ \\
\hline & $3.8 \mu \mathrm{M}$ ABA & $31.3 \mathrm{~cd} \pm 0.5$ & $89.8 c \pm 2.2$ & $72.9 \mathrm{~b} \pm 2.9$ \\
\hline & $2.15 \mathrm{mM}$ proline & $24.0 \mathrm{~b} \pm 0.3$ & $88.1 b c \pm 3.5$ & $63.5 \mathrm{a} \pm 2.1$ \\
\hline & $0.25 \mathrm{M}$ sucrose & 31.8 e \pm 0.7 & $83.1 \mathrm{~b} \pm 1.8$ & $69.6 \mathrm{~b} \pm 0.7$ \\
\hline \multirow[t]{4}{*}{ R. rubiginosa } & control & $22.5 \mathrm{ab} \pm 1.0$ & $53.0 \mathrm{a} \pm 3.0$ & $42.0 \mathrm{a} \pm 2.8$ \\
\hline & $3.8 \mu \mathrm{M}$ ABA & $31.5 \mathrm{~cd} \pm 0.6$ & $82.1 \mathrm{~b} \pm 2.1$ & $76.0 \mathrm{~b} \pm 2.5$ \\
\hline & $2.15 \mathrm{mM}$ proline & $24.1 \mathrm{~b} \pm 1.8$ & $82.0 \mathrm{~b} \pm 2.4$ & $79.2 \mathrm{~b} \pm 1.8$ \\
\hline & $0.25 \mathrm{M}$ sucrose & 32.7 e \pm 1.6 & $79.3 b \pm 2.1$ & $74.8 \mathrm{~b} \pm 3.3$ \\
\hline
\end{tabular}

* Means for the examined attributes with the same letter are not significantly different at $\alpha=0.05$; statistical analyses were performed separately for each rose species. 
Tab. 2 Morphological characteristic of rose plants: non-cryopreserved (control) and after shoot tips cryopreservation (post-cryo) and the acclimatization efficiency.

\begin{tabular}{|c|c|c|c|c|c|c|}
\hline \multicolumn{2}{|c|}{ Micropropagation stage } & \multicolumn{2}{|c|}{ Shoot multiplication } & \multicolumn{2}{|c|}{ Rooting } & \multirow[b]{2}{*}{$\begin{array}{l}\text { Acclimatized } \\
\text { plants }\end{array}$} \\
\hline Species & Treatment & $\begin{array}{c}\text { Shoot } \\
\text { multiplication rate }\end{array}$ & Shoot height (mm) & Rooted shoots (\%) & $\begin{array}{l}\text { Number of roots } \\
\text { per rooted shoot }\end{array}$ & \\
\hline \multirow[t]{2}{*}{ R. agrestis } & control & $1.0 \mathrm{a}^{*} \pm 0.1$ & $21.3 \mathrm{a} \pm 3.1$ & $62.7 \mathrm{ab} \pm 6.7$ & $2.1 \mathrm{~b} \pm 0.1$ & $100.0 \mathrm{~b} \pm 0$ \\
\hline & post-cryo & $1.2 \mathrm{a} \pm 0.1$ & $18.8 \mathrm{a} \pm 2.8$ & $66.7 \mathrm{a}-\mathrm{c} \pm 3.5$ & $3.4 \mathrm{f} \pm 0.3$ & $95.0 \mathrm{ab} \pm 5$ \\
\hline \multirow[t]{2}{*}{ R. canina } & control & $3.0 c \pm 0.7$ & $32.3 \mathrm{~b} \pm 2.5$ & $75.0 \mathrm{~d}-\mathrm{f} \pm 3.8$ & $2.6 c \pm 0.4$ & $93.0 \mathrm{a} \pm 5.3$ \\
\hline & post-cryo & $2.8 c \pm 0.8$ & $32.5 \mathrm{~b} \pm 3.8$ & $66.7 \mathrm{a}-\mathrm{c} \pm 4.7$ & $2.0 \mathrm{~b} \pm 0.1$ & $95.7 \mathrm{ab} \pm 5.9$ \\
\hline \multirow[t]{2}{*}{ R. dumalis } & control & $1.2 \mathrm{ab} \pm 0.1$ & $19.0 \mathrm{a} \pm 4.0$ & $70.8 \mathrm{c}-\mathrm{e} \pm 6.9$ & $1.8 \mathrm{a} \pm 0.2$ & $100.0 \mathrm{~b} \pm 0$ \\
\hline & post-cryo & $1.5 \mathrm{ab} \pm 0.1$ & $18.8 \mathrm{a} \pm 4.1$ & $59.0 \mathrm{a} \pm 4.3$ & $1.8 \mathrm{a} \pm 0.6$ & $100.0 \mathrm{~b} \pm 0$ \\
\hline \multirow[t]{2}{*}{ R. rubiginosa } & control & $2.0 \mathrm{~b} \pm 0.3$ & $26.8 \mathrm{~b} \pm 1.6$ & $89.3 \mathrm{~h} \pm 2.1$ & 3.3 ef \pm 0.2 & $97.0 \mathrm{ab} \pm 1.7$ \\
\hline & post-cryo & $1.9 \mathrm{~b} \pm 0.3$ & $30.3 \mathrm{~b} \pm 1.8$ & $79.5 \mathrm{fg} \pm 3.4$ & $2.1 \mathrm{~b} \pm 0.1$ & $100.0 \mathrm{~b} \pm 0$ \\
\hline
\end{tabular}

${ }^{*}$ Means for the examined attributes with the same letter are not significantly different at $\alpha=0.05$.

\section{Acknowledgments}

This study was supported by the Polish Ministry of Science and Higher Education (Grant No. N N310 142635 and DS 3500/KRO/2015).

\section{Authors' contributions}

The following declarations about authors' contributions to the research have been made: idea of the study: BP; laboratory research: BP; greenhouse research: BP, BST; data analyses: BST, BP; writing of the manuscript: BP, BST.

\section{Competing interests}

No competing interests have been declared.

\section{References}

1. Ritz CM, Schmuths H, Wisseman V. Evolution by reticulation: European dogroses originated by multiple hybridization across the genus Rosa. J Hered. 2005;96:4-14. http://dx.doi.org/10.1093/jhered/esi011

2. Panis B, Lambardi M. Status of cryopreservation technologies in plants (crops and forest trees). In: Ruane J, Sonnino A, editors. The role of biotechnology in exploring and protecting agricultural genetic resources. Rome: Food and Agriculture Organization of the United nations; 2005. p. 43-51.

3. Burritt DJ. Efficient cryopreservation of adventitious shoots of Begonia $\times$ erythrophylla using encapsulation-dehydration requires pretreatment with both ABA and proline. Plant Cell Tiss Organ Cult. 2008;95:209-215. http://dx.doi.org/10.1007/s11240-008-9434-5

4. Pawłowska B, Bach A. Cryopreservation by encapsulation dehydration of in vitro grown shoot buds of rosa 'New Dawn'. Acta Hortic. 2011;908:303-307. http://dx.doi.org/10.17660/ActaHortic.2011.908.40

5. Lynch PT, Harris WC, Chartier Hollis JM. The cryopreservation of shoot tips of Rosa multiflora. Plant Growth Regul. 1996;20:43-45. http://dx.doi.org/10.1007/BF00024056

6. Halmagyi A, Pinker I. Plant regeneration from Rosa shoot tips cryopreserved by a combined droplet-vitrification method. Plant Cell Tiss Organ Cult. 2006;84:145-153. http://dx.doi.org/10.1007/ s11240-005-9012-Z

7. Halmagyi A, Pinker I. Cryopreservation of Rosa shoot tips: importance of preculture conditions. Acta Hortic. 2006;725:351-356. http://dx.doi. org/10.17660/ActaHortic.2006.725.45

8. Pawłowska B. Cryopreservation of Rosa canina and R. rubiginosa apical buds by the droplet vitrification method. Acta Hortic. 2012;937:905910. http://dx.doi.org/10.17660/ActaHortic.2012.937.111

9. Le Bras CL, Besesrais PH, Hamama L, Grapin A. Cryopreservation of ex-vitro-grown Rosa chinensis ‘Old Blush' buds using dropletvitrification and encapsulation-dehydration. Plant Cell Tiss Organ Cult. 2014;116:235-242. http://dx.doi.org/10.1007/s11240-013-0400-5

10. Pawłowska B, Szewczyk-Taranek B. Droplet vitrification cryopreservation of Rosa canina and Rosa rubiginosa using shoot tips from in situ plants. Sci Hortic (Amsterdam). 2014;168:151-156. http://dx.doi. org/10.1016/j.scienta.2013.12.016

11. Agrawal A, Sanayaima R, Singh R, Tandon R, Verma S, Tyagi RK. Phenotypic and molecular studies for genetic stability assessment of cryopreserved banana meristems derived form field and in vitro explant sources. In Vitro Cell Dev Biol Plant. 2014;50:345-356. http:// dx.doi.org/10.1007/s11627-014-9606-4

12. Murashige T, Skoog F. A revised medium for rapid growth and bioassays with tobacco tissue cultures. Physiol Plant. 1962;15:473-497. http://dx.doi.org/10.1111/j.1399-3054.1962.tb08052.x

13. Harding K. Genetic integrity of cryopreserved plant cells: a review. Cryo Letters. 2004;25:3-22. 